\title{
Comparing community garden typologies of Baltimore, Chicago, and New York City (USA) to understand potential implications for socio-ecological services
}

\author{
Elsa C. Anderson ${ }^{1}$ (D) $\cdot$ Monika H. Egerer ${ }^{2} \cdot$ Nakisha Fouch $^{3} \cdot$ Mysha Clarke $^{4} \cdot$ Melissa J. Davidson $^{5}$
}

Published online: 26 April 2019

(C) The Author(s) 2019

\begin{abstract}
Urban community gardens offer unique social and ecological benefits in cities. However, given the dynamic nature of cities and the profound effects of variable land uses on green space provisioning for people and wildlife, investigating community gardens from a landscape perspective offers valuable insight into the functions of these spaces in terms of ecosystem services and sustainable development. In this study, we use garden locations provided by stakeholder groups and fine-scale spatial data to compare community gardens across three cities: New York City, NY, Chicago, IL, and Baltimore, MD (USA). In each city, we assess the spatial distribution of gardens and compare the natural vegetation and impervious surface cover within these gardens to the surrounding neighborhood and landscape. We then compared these cities to clarify the role of community gardens in metropolitan development. Our findings demonstrate that gardens cluster in neighborhoods in New York City and Chicago, but they are more spatially distributed across the landscape in Baltimore. The distribution of Baltimore's community gardens is more likely to be contributing to a greater network of ecosystem services across a broader urban landscape. Moreover, at the garden scale, gardens in NYC and Chicago have more canopy cover and built infrastructure than the more herbaceous gardens in Baltimore. This suggests that our case study cities exhibit different garden typologies, histories, and potential for ecosystem services. This work provides critical insight into the typology in and around community gardens in different cities, which is useful in understanding the potential ecosystem services and planning trajectories of these cities.
\end{abstract}

Keywords Distribution · Ecosystem services · Green infrastructure $\cdot$ Land use $\cdot$ Urban agriculture $\cdot$ Urban greening

\section{Introduction}

More than five billion people worldwide will live in cities by 2030. In the United States of America alone, nearly 300 million people live in urban areas (United Nations, Department of Economic and Social Affairs 2015). Consequently, cities are not only places where people live and work, but are also increasingly where people seek outdoor recreation and interactions with the natural world (Russell et al. 2013). In response to rapid urbanization, urban planners and municipal land managers are incorporating public needs and desires for urban green space and green infrastructure in urban policy, planning,

\author{
Elsa C. Anderson \\ eholden2@uic.edu \\ Monika H. Egerer \\ megerer@ucsc.edu \\ Nakisha Fouch \\ nfouch@clemson.edu \\ Mysha Clarke \\ mysha.clarke@gmail.com \\ Melissa J. Davidson \\ mjdavids@asu.edu
}

Department of Biological Sciences, University of Illinois at Chicago, 845 W Taylor St. MC/066, Chicago, IL 60607, USA

2 Department of Environmental Studies, University of California, Santa Cruz, CA, USA

3 Department of Wildlife and Fisheries Biology, Clemson University, Clemson, SC, USA

4 Department of Geography \& the Environment, Villanova University, Villanova, PA, USA

5 School of Sustainability, Arizona State University, Tempe, AZ, USA 
and revitalization projects (Gill et al. 2007; Tzoulas et al. 2007). The benefits of urban ecosystems and greening are well documented, especially within the ecosystem service literature and discourse (Bolund and Hunhammer 1999; Chiesura 2004; Hansen and Pauleit 2014). Some of these benefits include: climate regulation, stormwater capture, biodiversity conservation, and food production (Eigenbrod et al. 2011). Green spaces also provide critical cultural services to residents including physical and mental health benefits, social cohesion, education, and cultural maintenance (Fuller et al. 2007). Therefore, green spaces are important for the overall biophysical and social wellbeing of city residents. Furthermore, the distribution of green spaces across urban landscapes is a critical component of equity and environmental justice.

Urban community gardens are a type of green space that provide a full suite of these provisioning, regulating, supporting, and cultural ecosystem services (Lovell and Taylor 2013; Lin et al. 2015; Clarke et al. 2019). Due to their multifunctionality (Lovell 2010), community gardens have become more popular and prominent in a number of US cities (Lawson 2005). This transformation into productive community gardens across urban landscapes has occurred in different patterns in diverse cities (Bailkey and Nasr 1999). However, to our knowledge, few have investigated the patterns in community garden typology that these transformations produce over time. In urban planning, a typology is defined as a classification of characteristics of urban spaces according to their bio-social associations (Moneo 1978). While it is well established that cities have unique histories and ecologies (Hayden 1997; Pickett et al. 2011; Nassauer and Raskin 2014), typological assessments of community garden land cover and juxtaposition within the broader urban landscape offers insight into the generalizable trends that may exist within and between city gardening programs. More so than a block- or neighborhood-scale assessment, evaluating the entire landscape of a city provides the opportunity to uncover generalizable land cover features (i.e. urban typologies) within and around community gardens. This fills a critical gap in our understanding of how community gardens are shaped by and contribute to urban landscapes, which allows us to better understand how these spaces contribute to the ecology of whole cities. Characterization of community garden typologies within and between cities is also invaluable to urban planners and garden supporters as they forecast growing urban agriculture popularity in the context of urban development.

Community gardens are considered 'vital urban spaces' relative to their landscape surroundings and the broader urban context (Sullivan et al. 2004). Therefore, establishing a landscape typology of community gardens provides a baseline for assessing their ecological potential at several scales. At the landscape scale, urban green spaces that are closer together may better conserve biodiversity (Cook 2000; Parker et al.
2008) and provide ecosystem services (Zipperer et al. 2000). Alternatively, distributed green spaces help regulate climate and other urban environmental stressors (Mathey et al. 2011). At the local garden scale, individual sites provide habitat for mobile organisms like birds and support high arthropod diversity (e.g., bees, spiders, beetles; Smith et al. 2006; Sattler et al. 2010; Goddard et al. 2010) - thereby providing pollination and natural pest control services to gardeners (Lin et al. 2015). At an intermediate scale (i.e. block or neighborhood level, see Minor et al. 2018), the ecological communities supported by gardens and the resulting ecosystem services are decidedly different than those found in other urban land types (Corlett et al. 2003; Galluzzi et al. 2010; Gardiner et al. 2014; Speak et al. 2015). Due to the landscape heterogeneity of cities, these fine-scale differences in plant communities and ecosystem services combine to create larger-scale patterns on the landscape (Cadenasso et al. 2007). Therefore, a holistic understanding of community garden ecology is predicated on understanding the typologies of the city context, the community gardens themselves, and the areas directly adjacent to community garden sites.

A review by Guitart et al. (2012) found that only $1 \%$ of papers published on community gardens focused on their potential for conservation-related services, and most research does not quantify or address the physical characteristics of gardens. However, community garden function depends largely on morphology (e.g., tree presence, built structures) and cultivation intensity (e.g., food produced) (Burdine and Taylor 2017), which ultimately changes the use and utility of the space (Saldivar-Tanaka and Krasny 2004). For example, gardens with more trees - and thus shade - may better regulate local climate (Lin et al. 2018) and improve the aesthetics and the nature experiences of gardeners (Nowak and Dwyer 2007). Yet, it is likely that there is relatively less food produced in these shaded gardens. Alternatively, larger community gardens with fewer trees and more intensively cultivated space may provide more gardening opportunities and food to residents. Larger gardens may also increase the conservation of pollinators (Quistberg et al. 2016) and natural enemies (Burks and Philpott 2017) - thereby improving pest control services (Philpott and Bichier 2017). While these trade-offs paint a complex picture within a given space, a broader understanding of the biophysical features and landscape contexts of community gardens across a city offers important insight into the actual functions and provisions of gardens as a land type rather than as individual case studies.

In this paper, we use three US cities to identify key patterns and differences in the biophysical features of community gardens at the city landscape, local garden, and directly adjacent scales. We focused on New York City (NYC), New York; Chicago, Illinois; and Baltimore, Maryland, because these 
cities have different urbanization patterns but share a rich history of community gardening movements, both at the grassroots and top-down organizational levels (Staeheli et al. 2002; Lawson 2005; Baltimore City Planning Commission 2013). Furthermore, city planners, organizations, and residents in these cities are beginning to incorporate community gardens into urban revitalization projects and plans (City of Chicago Department of Planning and Development 2007; Baltimore City Planning Commission 2013; The City of New York 2015). Thus, city-scale analyses can provide information about the distribution of and access to ecosystem serviceproviding green space to policy makers and planners (Pulighe et al. 2016).

Given the contemporary development patterns and the history of urban agriculture in the cities as well as the urgent need to understand and plan for ecosystem services in the Anthropocene, we evaluated the variation of gardens using a within-garden scale and a between-city scale. Specifically, we asked three questions: 1) what are the biophysical and spatial features within community gardens and surrounding gardens in NYC, Chicago and Baltimore? 2) How do within-garden features compare to surrounding landscape features? 3) Do biophysical and spatial features of gardens differ between cities? We hypothesized that the typology of gardens themselves (i.e., the garden scale) would be fairly similar in NYC, Chicago, and Baltimore given the goals and histories of garden development. However, we predicted that there would be significant differences in garden landscape typology between cities. Particularly, we expected there to be different distribution patterns (clustered or dispersed), as these result from cityspecific patterns of land-use and development. Overall, we aimed to provide a clear typology of community gardens for each city, and to uncover generalizable patterns in the describing the biophysical characteristics of gardens across three cities.
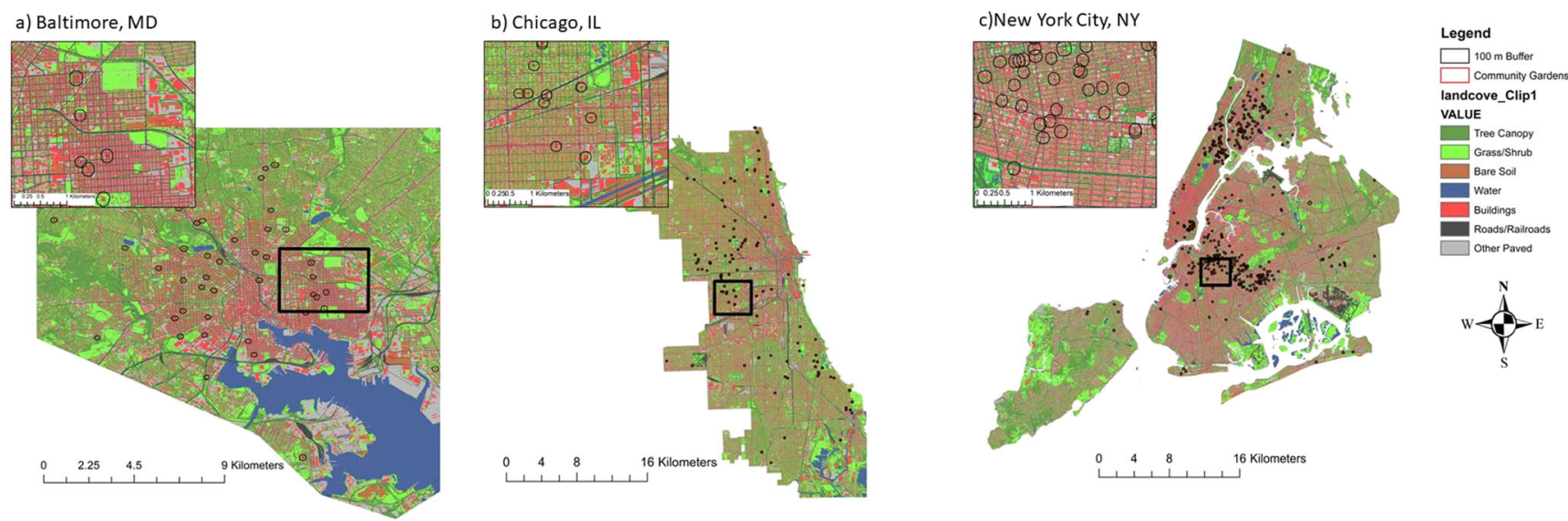

Fig. 1 Spatial analysis of gardens and their landscape surroundings in (a) Baltimore, (b) Chicago, and (c) NYC. Subset maps show the typical typology surrounding community gardens (outlined in red), and the $100 \mathrm{~m}$ buffers surrounding the gardens (outlined in black)

\section{Methods}

\section{The cities}

To assess the typology for community gardens, we examined the biophysical form of each of the three US cities (Fig. 1, US Census Bureau 2016). Each city is at a different phase of postindustrial urbanization, transition and community reorganization (Delmelle 2019; Florida and Adler 2018). This phase is generally associated with land use change, urban sprawl and changing neighborhood dynamics (Delmelle 2019; Florida and Adler 2018). Moreover, the cities have all undergone dramatic urban land use change in at least the past two decades, though these changes have occurred differently. NYC has grown in population and in density while Baltimore - and to a lesser extent Chicago - have lost residents and declined in building/housing density (US Census Bureau 2014).

We chose these three cities because they have a long history of urban agriculture dating back to the Second World War. Victory gardens were planted in vacant and peripheral green space habitat to grow fresh fruits and vegetables (Lawson 2005). As a prime example, Chicago led the nation in wartime urban food production with over 1500 community gardens and 250,000 home gardens, and served as model for victory garden programs in other cities (Lawson 2005). Some of these gardens (e.g., North Park and Rainbow Beach Community Garden) continue to be cultivated today (Taylor and Lovell 2012). NYC has had more recent urban agriculture movements in the 1980s in response to the economic recession (Eizenberg 2012). However, these gardens have been contested spaces between community groups and development over the past decades due to gentrification and high housing demands (Schmelzkopf 1995, 2002). In contrast to NYC, Chicago and Baltimore are considered shrinking cities (United States Census Bureau 2014). In Baltimore, large 
vacant lots are currently being converted into community green spaces like parks and community gardens. Of note, the Baltimore City Mayor established the Urban Gardening Task Force in 1980 to increase food production and nutrition within low income communities, and more recently (circa 2008) the city adopted the Baltimore Sustainability plan, the Baltimore Food Policy Task force, and a Vacant to Value initiative online (Baltimore City Planning Commission 2013), all of which promote community garden establishment.

\section{Community gardens}

\section{Garden selection and validation}

In each city, we worked with one well-established stakeholder group that support community gardens (NYC, Green Thumb; Chicago, NeighborSpace; Baltimore, Baltimore Green Space) to obtain information about city-sanctioned gardens. We chose to work with these stakeholder groups because they have a long standing rapport in these cities and their associated gardens are more likely to be well-established rather than ephemeral gardens that do not persist. These stakeholder groups represent the single best authority in each city on garden definitions, locations, longevity, and culture, which standardized our approach for this project in a way that other methods of garden identification could not. Each group provided the spatial location of the community gardens that they work with, and we mapped and validated the existence of each garden site using Google Earth Pro@ imagery from 2017 and 2011 (when available). For each garden, we used Street View@ to confirm that the garden existed and was under cultivation. We eliminated sites on the basis of abandonment or development only if there was clearly no longer a garden at that space (e.g. it was built or under construction) as image details were not always high enough resolution to ascertain cultivated plots from spontaneous vegetation. We eliminated gardens that were in school yards or in in parkways or meridians for several reasons. School yard represented less than $8 \%$ of all stakeholder garden listings in each our cities. Furthermore, they are rarely accessible to the general public and often do not receive their highest cultivation during the summer growing season. Parkway and meridian gardens are quite narrow, often $<1 \mathrm{~m}$ wide. As such, they are beyond the spatial resolution capacities of our data sets. Because of this, they are also unlikely to be spaces where people congregate or recreate, and are therefore tangential to many of the cultural ecosystem services of community gardens.

We measured the size of each garden and digitized polygons of the full area of 476 community gardens in NYC, 116 in Chicago, and 43 in Baltimore. While a stakeholderinformed approach standardized our method, we acknowledge that not all community gardens in each city are included in our analysis. A true number of sites serving as community gardens in a given city is notoriously hard to pinpoint. However, based on best estimates of large food-producing spaces on vacant or public land, we are confident that our stakeholder informed sites represent at least $70 \%$ of comparable gardens in each of our cities (Taylor and Lovell 2012; Matteson et al. 2008).

\section{Landscape analysis}

To determine the biophysical features associated with gardens at the city landscape scale and at the garden scale, we collected high resolution land cover imagery for each city from the University of Vermont Spatial Analysis Laboratory, which is rasterized based on LiDAR and NAIP satellite imagery (Baltimore 2007; Chicago 2010; New York City 2010). These spatial data classify tree canopy cover, grass/shrub cover, bare soil, standing or open water, buildings, roads/railroads, and other paved surfaces at a $1 \times 1 \mathrm{~m}$ resolution. Even though this data was almost a decade old at the time of this study, it is the finest spatial resolution available and changes in urban land use over time at this scale are unlikely to be dramatic given the coarse land use classifications. We combine tree and grass/shrub cover into the category "natural vegetation" and buildings, roads/railroads, and other paved into the category "impervious surface". We overlaid our garden polygons onto these fine scale rasters and used a zonal tabulation to assess the percentage of each land cover type within gardens. To measure the landscape features directly surrounding gardens, we created a $100 \mathrm{~m}$ fixed-radius buffer around each garden polygon, excluding the garden area itself, and calculated the percentage cover of each land cover category within this $100 \mathrm{~m}$ buffer. In this all of our case studies, a $100 \mathrm{~m}$ buffer extending from the garden polygon itself encompasses approximately one city block, which helps capture the variation at a fine scale. This was done in ArcGIS v 10.5 with the Tabulate Features to Percent tool in the Selection and Area Processing toolset (NAWQA_Area-Characterization Toolbox (Price et al. 2010)). We also calculated the proportion of each land cover type for the entirety of each city.

We did two brief assessments on physical properties of cities that concern garden accessibility to local residents. First, we compared the mean Euclidean distance of each garden to transportation thoroughfares accessible by bus or personal vehicles. To assess differences in accessibility for residents of different transportation means, we did this separately for major highways and smaller residential streets (see https:// www.census.gov/geo/reference/mtfcc.html for the road category definitions by the US Census Bureau). Second, we compared the number of households who benefit from living in close proximity to a community garden. To do this, we compared the American Community Survey (ACS 20112016) housing density (units per $\mathrm{km}^{2}$ ) between block groups with community gardens and those without. 


\section{Statistical analysis}

\section{Within cities}

To determine the spatial distribution of gardens across the urban landscapes, we calculated a nearest neighbor ratio (NNR) for gardens in each city. NNR is based on a $\chi^{2}$ analysis and is equal to the observed distance to a nearest neighbor (i.e., another garden) divided by the expected distance to a nearest neighbor given a random distribution. This metric is useful in comparing different data sets (i.e. cities) because it calculates a metric that is based on the inherent structure of the data rather than one that is influenced by increasing sample size or area (Fahey and Casali 2017). If gardens are randomly distributed, then the NNR should equal one. An NNR greater than one indicates equal dispersion and an NNR less than one indicates clustering.

In order to ascertain differences between the natural vegetation and impervious surface cover at various spatial scales, we used one-sample t-tests with the calculated land cover for each city as our known means. We compared this city-wide mean to the $100 \mathrm{~m}$ buffer surrounding gardens in each city. In order to more fully assess the density of the built area around our gardens, we used two-sample t-tests to compare the mean housing density (per $\mathrm{km}^{2}$ ) of the American Community Survey (ACS) Block Groups that contained gardens with the mean housing density of all block groups in the city (ACS 2011-2016).

\section{Between cities}

In order to statistically assess the differences between garden patterns in NYC, Chicago, and Baltimore, we used one-way Analysis of Variance (ANOVA) with Tukey's Honestly Significant Difference (HSD) test and assigned significance at $\alpha=0.05$. We considered anything with $\alpha<0.1$ to be moderately significant. We compared mean community garden size and surrounding landscape composition. We ran four separate landscape composition models between cities; 1) mean proportion of green space and 2) impervious cover in the area surrounding gardens (100 m buffer) and 3 ) mean proportion of green space within gardens and 4) impervious surface within gardens. To assess accessibility and service potential to local residents, we calculated the mean distance to a) large highways and b) two-way residential roads as well as the c) housing density in the surrounding $100 \mathrm{~m}$ fix-distance buffers surrounding community gardens between cities. To better assess housing density near our gardens, we calculated the average number of households within the $100 \mathrm{~m}$ fixed radius buffer surrounding our gardens by multiplying the block group housing density by the area of the buffer polygon. We then used three one-way ANOVAs to independently assess how gardens relate to these features. No values were transformed or corrected because the raw data met assumptions of normality for our assessment, and were independent when green space and impervious surface were compared separately.

\section{Results}

\section{Within cities}

We found that community gardens were significantly clustered across the city in Chicago (Nearest Neighbor Ratio 0.058; ANOVA $P<0.001)$ and NYC $(0.42 ; P<0.0001)$, but were much more equally dispersed across Baltimore (1.14; $P=0.083$; Table 1). Community gardens in NYC were located in areas that are more densely built compared to the city as a whole. That is to say that, within the $100 \mathrm{~m}$ buffers, there was a greater proportion of impervious surface and a lower proportion of natural vegetation compared to the overall mean proportion of each land cover across the city (Table 2). Chicago and Baltimore had more impervious surface surrounding gardens than the city mean, but the amount of green space was comparable to the city as a whole (Table 2). NYC gardens were located in areas with significantly higher housing density than the city average (Table 2 ).

\section{Between cities}

Overall community gardens represented a small percentage of land cover in the cities (Baltimore: 0.02\%; Chicago: 0.001\%; NYC: $0.004 \%)$, and were similar in mean ( \pm SE) size (Baltimore: $852 \pm 132 \mathrm{~m}^{2}$, Chicago: $717 \pm 65 \mathrm{~m}^{2}$, NYC: 735 $\pm 58 \mathrm{~m}^{2}$ ) across cities (ANOVA, $\mathrm{F}_{2}, 632=0.37 ; P=0.69$ ). In relation to other city features, Baltimore gardens were

Table 1 Analysis of garden configuration on the landscape using Nearest Neighbor Ratios (NNR)

\begin{tabular}{llllc}
\hline City & Mean $( \pm$ SE) garden size & Observed mean distance between gardens & Ratio & Z \\
\hline Baltimore & $852 \pm 132 \mathrm{~m}^{2}$ & $987.23 \mathrm{~m}$ & 1.14 & 1.73 \\
Chicago & $717 \pm 65 \mathrm{~m}^{2}$ & $2282.54 \mathrm{~m}$ & 0.06 & -8.61 \\
NYC & $735 \pm 58 \mathrm{~m}^{2}$ & $314.87 \mathrm{~m}$ & 0.42 & -24.17 \\
\hline
\end{tabular}

The presented NNR is the ratio of the observed distance to another garden versus the mean distance between gardens. These values indicate that there is significant clumping of gardens in Chicago and NYC, but not in Baltimore

Bolded $p$ values indicate significant results at $\alpha=0.05$ 
Table 2 T-test results of the significant differences between the amount of (a) impervious surface, (b) green space, and (c) housing density in areas surrounding gardens in each of the three cities

\begin{tabular}{llllll}
\hline City & City mean $( \pm \mathrm{SD})$ & Garden buffer mean $\pm \mathrm{SD}$ & $\mathrm{df}$ & $\mathrm{t}$ & $p$ \\
\hline $\begin{array}{l}\text { a. Impervious surface } \\
\text { Baltimore }\end{array}$ & $43.48 \%$ & & & & \\
Chicago & $52.09 \%$ & $60.19 \% \pm 23.11$ & 42 & 4.74 & $<\mathbf{0 . 0 0 1}$ \\
NYC & $59.09 \%$ & $55.12 \% \pm 14.33$ & 115 & 2.28 & $\mathbf{0 . 0 2}$ \\
b. Green space & & $78.52 \% \pm 10.55$ & 475 & 40.19 & $<\mathbf{0 . 0 0 1}$ \\
Baltimore & $42.92 \%$ & & & & \\
Chicago & $42.37 \%$ & $41.11 \% \pm 23.64$ & 42 & 0.50 & 0.62 \\
NYC & $37.85 \%$ & $44.27 \% \pm 14.10$ & 115 & 1.45 & 0.15 \\
c. Housing density & $21.33 \% \pm 10.40$ & 475 & 34.64 & $<\mathbf{0 . 0 0 1}$ \\
Baltimore & $2589.36 \pm 1853.58 / \mathrm{km}^{2}$ & $2496.84 \pm 2151.71 / \mathrm{km}^{2}$ & 704 & 0.31 & 0.75 \\
Chicago & $4272.36 \pm 6812.43 / \mathrm{km}^{2}$ & $3343.40 \pm 2203.809 / \mathrm{km}^{2}$ & 2071 & 1.46 & 0.14 \\
NYC & $8466.24 \pm 7667.66 / \mathrm{km}^{2}$ & $10,980.76 \pm 6241.13 / \mathrm{km}^{2}$ & 2672 & 6.69 & $<\mathbf{0 . 0 0 0 1}$ \\
\hline
\end{tabular}

Impervious surface and green space were calculated in $100 \mathrm{~m}$ buffers and were analyzed using one-sample t-tests, while housing density was extracted at the block-group level and analyzed using a two-sample t-test

Bolded $p$ values indicate significant results at $\alpha=0.05$ significantly further from highways than those in Chicago and NYC (ANOVA, $\mathrm{F}_{2,632}=1583.79 ; P<0.0001$ ), whereas the differences between Chicago and NYC were moderately significant (Tukey's HSD, $P=0.0585$ ). However, Chicago gardens were significantly further from residential roads than gardens in NYC or in Baltimore (ANOVA, $F_{2}, 632=21.2$; $P<0.0001)$, and there was no significant difference between NYC and Baltimore (Tukey's HSD, $P=0.99$ ). There are, on average, 345 households within $100 \mathrm{~m}$ radius of a community garden in NYC. This was significantly denser than Chicago (Tukey's HSD $p<0.0001$ ) or Baltimore (Tukey's HSD $\mathrm{p}<$ 0.0001 ), where the averages were 105 and 78 households respectively (ANOVA $F_{2}, 632=121.4 ; P<0.0001$, Tukey's HSD $p=0.66)$.
Community gardens were surrounded by different amounts of impervious surface and green space among cities (Fig. 2). Within the $100 \mathrm{~m}$ buffers surrounding gardens, NYC has significantly greater proportion of impervious surface (ANOVA, $\mathrm{F}_{2,632}=190.2 ; \mathrm{P}<0.0001$; Table 2; Fig. $2 \mathrm{~b}$ ) and significantly less natural vegetation (ANOVA, $\mathrm{F}_{2}, 632=189.5 ; \mathrm{P}<0.0001$ ) compared to Chicago and Baltimore, which did not differ significantly (Tukey's HSD impervious surface: $P=0.058$; green space: $P=0.32$; Table 2 ).

Individual gardens had different amounts of impervious surface and natural vegetation between cities (Fig. 2a). On average, Baltimore gardens had approximately $15 \%$ more natural vegetation and therefore less impervious cover compared to NYC and Chicago (natural vegetation: ANOVA: $\mathrm{F}_{2,632}=$
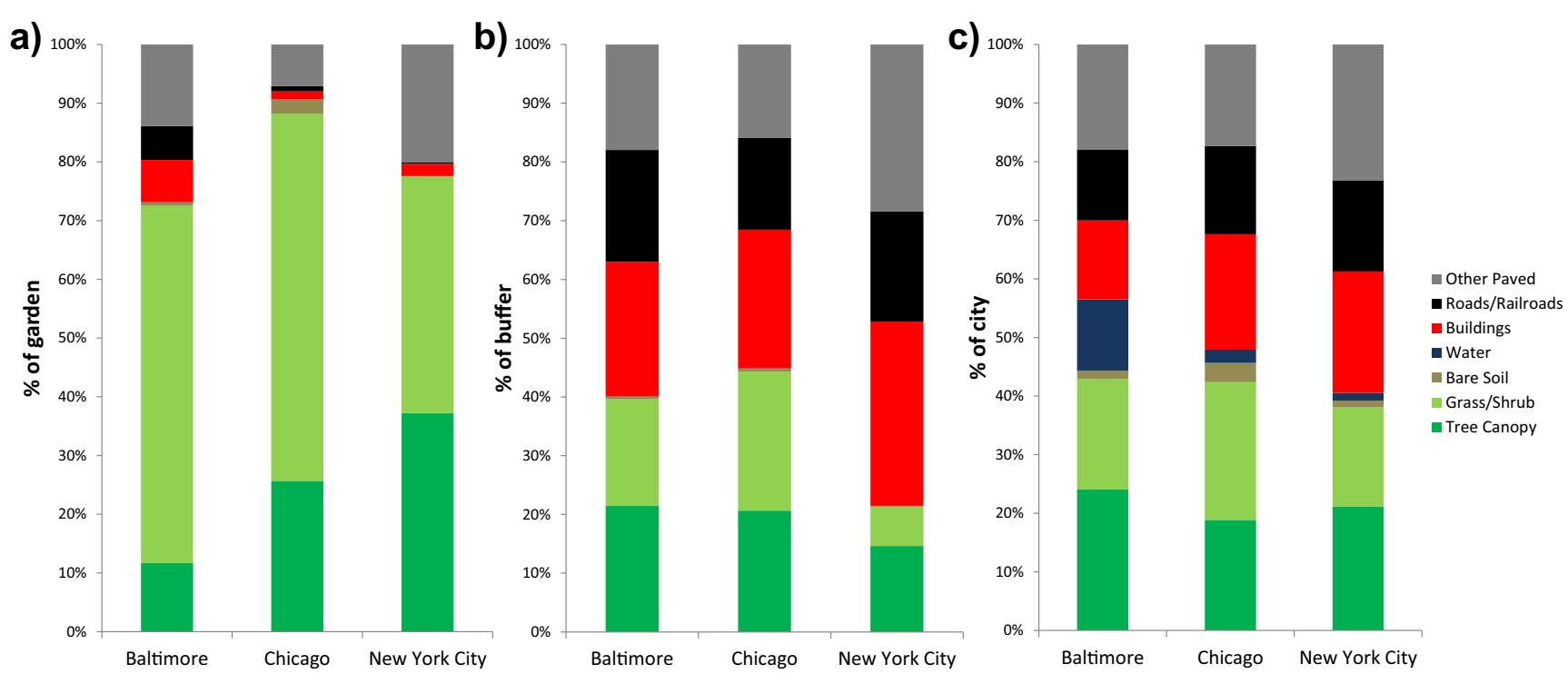

Fig. 2 Percentages of land area covered by different land uses in (a) urban community gardens, (b) $100 \mathrm{~m}$ buffers surrounding gardens, and (c) the whole city for Baltimore $(N=43)$, Chicago $(N=116)$, and New York City $(N=476)$ 
11.36, $P<0.001$; impervious cover; ANOVA: $\mathrm{F}_{2,632}=16.66$; $\mathrm{P}<0.001)$. NYC and Chicago did not differ from one another in green space (Tukey's HSD, $P=0.37$ ) or impervious surface (Tukey's HSD, $P=0.43$ ) (Table 2; Fig. 2c). When we divided the natural vegetation category into its composite parts, Baltimore gardens had a greater proportion of grass/shrub vegetation than Chicago and NYC gardens, which both had greater canopy cover than those in Baltimore (Fig. 2a).

\section{Discussion}

Community gardens in NYC, Chicago, and Baltimore have a rich history of providing valuable social and ecosystem services. However, current understanding of community gardens fails to connect their morphology and distribution across city landscapes with their capacity for improving urban environments at a large scale. Our assessment of the spatial distribution and biophysical and morphological differences of community gardens in three cities works towards generating a multi-scale typology of community gardens across city landscapes. We show that there are distinct community garden distributions across the landscape and that community gardens differ dramatically in their morphology between the three cities examined. Specifically, community gardens in NYC, Chicago, and Baltimore have differing patterns of canopy cover and herbaceous vegetation. Finally, community gardens in all three cities are within surrounding areas that are distinct from the broader patterns of the urban landscape, serving as green space in residential areas with high impervious surfaces. These patterns collectively contribute to systemic and city-wide understandings of land use surrounding community gardens at different spatial scales. They also pave the way for a broader understanding of how community gardens can contribute to urban sustainability goals through wildlife habitat and potential ecosystem service provision.

Community gardens differed in their distribution across cities. At the landscape scale, we found that community gardens are clustered within certain neighborhoods in NYC, and to a lesser extent in Chicago, but are more spatially dispersed across Baltimore. Although the community gardens we assessed represent only $0.02 \%$ of the land area in Baltimore, their dispersed distribution suggests that these gardens could contribute to a greater city-scale green space network. This is further supported by the relatively high proportion of canopy and herbaceous cover in area surrounding Baltimore gardens. Alternatively, the clustering of community gardens in NYC neighborhoods provides a stark contrast. The clustered distribution of community gardens in NYC can be attributed to the history of the urban agriculture movement in the 1980s when community gardens were established in neighborhoods such as the Lower East Side (Green Thumb, pers. comm). The Lower East Side community gardens have been the subject of many neighborhood-scale assessments since their establishment (e.g. Schmelzkopf 1995;
Smith and Kurtz 2003). Today, these community gardens are well-funded and sanctioned green spaces, meaning they are highly unlikely to be contested or demolished. Moreover, these community gardens were largely established through the efforts of a few invested garden coordinators who worked to create new sites close to existing community garden spaces as land and community interest became available (Green Thumb, Pers. comm). This facilitates sharing resources and knowledge between sites, and also likely increases environmental quality at the neighborhood scale. As such, this clustered model could provide extensive cultural ecosystem services where local residents can participate in "communities-of-practice" (Barthel et al. 2010), but is limited in the capacity of offering city-wide benefits.

The dense urban typology surrounding community gardens in these cities in contrast to the relatively high proportion of canopy cover and green space within gardens (Fig. 2) alludes to the importance of community gardens as green spaces for cultural and restorative ecosystem services (Kuo 2003; Sullivan et al. 2004; Fuller et al. 2007). Even though it was fairly common that a $100 \mathrm{~m}$ buffer in some NYC neighborhoods included another community garden, the impervious surface surrounding NYC gardens was more than $15 \%$ higher than that in Chicago and Baltimore. This detracts from the functional ecological connectivity of these gardens, as they lack the necessary intermediary green spaces, limiting their utility as habitat stepping stones (Hostetler and Holling 2000; Beninde et al. 2015; Myint et al. 2015). While Baltimore and Chicago also have gardens in dense urban areas, the amount of green space in the surrounding buffers is comparable to that of the city as a whole. This suggests that community gardens in all of the cities are located in relatively densely built areas; however, the relative "greenness" of the neighborhoods surrounding community gardens differs among the cities. Therefore, in very dense cities like NYC, small community gardens may be critical places where local residents can easily access green space. Access and exposure to green space, even in small doses such as along a commute or out a window, has positive effects on health and wellbeing (Kaplan 1993; Larsen et al. 1998; Grinde and Patil 2009). Furthermore, access to community gardens directly engages community members in local conservation efforts (Ohmer et al. 2009).

Counter to our predictions, community gardens in NYC, Chicago, and Baltimore have distinct within-garden typologies. The community gardens in NYC and Chicago had more established trees and greater canopy cover than those in Baltimore (Fig. 2). This difference is likely attributed to the history and ages of these community gardens. Even though Baltimore has historically had urban agriculture (Baltimore City Planning Commission 2013), the current community gardens (and particularly those analyzed in this study) likely represent a new wave of urban greening prompted by the city's deindustrialization (Herrmann et al. 2018). The stakeholder organization ages may explain this difference. Baltimore Green Space is a relatively new organization established in 2007 
(http://baltimoregreenspace.org/) while NYC's Green Thumb was initiated in 1970, nearly four decades earlier (http:/www. greenthumbnyc.org/about.html). It makes sense that NYC gardens have more trees, as trees are a slow growing investment in urban green spaces and require long-term maintenance and care by land managers and residents (Locke and Grove 2016). The resulting disparity in canopy cover has implications for biodiversity (Hostetler and Holling 2000). For example, the abundance and diversity of beneficial arthropods in community gardens is correlated with greater tree abundance and diversity (Burks and Philpott 2017), and greater canopy cover and structural vegetation diversity is associated with greater native and specialist avifauna in urban landscapes (Chace and Walsh 2006). Moreover, gardens without trees may not provide the social benefits of long standing vegetation, such as shade and urban cooling. However, it is also worth noting that ecosystem services are impacted by fine-scale differences in cultivation and management (Clarke and Jenerette 2015). City-wide data on these practices from all gardens in question does not exist. Future work in understanding the true ecological functions of community gardens would benefit from extensive and standardized vegetation sampling across all gardens in various cities.

The higher herbaceous cover may also indicate that Baltimore gardens are geared towards larger-scale food production, although this study did not directly assess that. Many neighborhoods in Baltimore are considered food deserts (Corrigan 2011) - areas in which access to fresh fruits and vegetables are extremely limited (Walker et al. 2010). Indeed, some of the Baltimore community gardens are operating under a Community Supported Agriculture (CSA) business model and are more similar to small farms run by a community rather than the typical allotment gardens historically and presently seen in Chicago and NYC (Lawson 2005). While we do not examine the structural or business models of gardens here, more work to understand the differences in garden social function would help clarify the extent to which community gardens actually alleviate crisis associated with food insecurity. Regardless, our results demonstrate that Baltimore gardens are more evenly dispersed, have higher herbaceous vegetation cover, and make up a larger percentage of the urban land area. These patterns suggest that community gardens in Baltimore have the biophysical capacity to contribute to food equity, which builds on the needs and priorities of the city (Corrigan 2011; Liskey 2017). To understand how cities can better manage ecosystem services, we should strategically position community gardens in broader urban sustainability and resilience contexts (Clarke et al. 2019. Particular attention should be paid to how community gardens are situated in a broader greenspace context throughout cities, as ecosystem services and habitat provisioning are augmented by being closely intertwined with other green spaces (Minor et al. 2018). This contextualization of community gardens will enhance the provisioning of ecosystem services under diverse conditions and provide benefits to a wider population, and can better target garden development towards neighborhoods that would benefit most. Furthermore, although community gardens are supported by top-down groups such as Green Thumb or Neighborspace, they also require intensive resident involvement. As community gardens continue to develop in response to hardship, understanding the patterns at the city scale can help maximize utility and support "just green enough" urban environmental improvements (Wolch et al. 2014).

To our knowledge, this is one of the first studies that systematically examines and compares the landscape patterns of community gardens in multiple cities. Community gardens are known to have extensive benefits for local residents and individual ecologies in a dense urban matrix. However, no plot of land in a city operates in isolation. Grove et al. (2015) recommend that urban studies clearly define land-type margins in order to put distinct, small-scale land uses in concert with one another. Investigating community gardens as an urban land-type provides a critical birds-eye view of urban socio-ecological function. Additionally, contributing to a city-specific or more general community garden typology provides insight into how the biophysical patterns on the landscape relate to ecological processes. Cities such as NYC, Chicago, and Baltimore have experienced different historic and socio-political pressures which have contributed to distinct garden distributions and typologies over time. These distinct historical features and contemporary typologies also support the need for expansion of large-scale thinking about community gardening to other cities. This project bolsters our knowledge of how the city-wide distribution and the land-use composition in and around community gardens can contribute to ecosystem services and urban resilience across an entire urban landscape (Clarke et al. 2019). Using socio-environmental methods to untangle these complexities can provide city planners and community garden stakeholders with much-needed empirical, large-scale evidence to create community garden plans and policies that help foster healthy urban environments for people and nature.

\section{Conclusion}

In the US, cities are growing or shrinking due to changing economies and demographics. These urbanization processes change the urban form of cities, particularly the availability and distribution of urban green spaces. Understanding the distribution and morphology of green spaces like community gardens in relation to the landscape context across changing urban regions is critical for informing city policy and planning. Here we demonstrate that while community gardens in NYC are established and have a long history in the city, their clustering in certain neighborhoods reveals that from a spatial perspective they are not necessarily providing distributed ecosystem services across the greater urban landscape in comparison to Baltimore. Using gardens as an example, the results lends insight into how densifying cities 
and shrinking cities compare and contrast in their green space provisioning, and where and how cities should focus their efforts on garden establishment if they aim to promote diverse ecosystem services in the future.

Acknowledgements We thank the National Socio-Environmental Synthesis Center (SESYNC) for supporting this research. Thank you to $M$ Grove for assistance with research design and contacts with stakeholder groups. Special thanks to NYC's Green Thumb, Chicago's NeighborSpace and Baltimore Green Space for sharing data sets and imparting insight into our analysis.

Open Access This article is distributed under the terms of the Creative Commons Attribution 4.0 International License (http:// creativecommons.org/licenses/by/4.0/), which permits unrestricted use, distribution, and reproduction in any medium, provided you give appropriate credit to the original author(s) and the source, provide a link to the Creative Commons license, and indicate if changes were made.

\section{References}

Bailkey M, Nasr J (1999) From brownfields to greenfields: producing food in north American cities. Community Food Security News Fall 2000:6

Baltimore City Planning Commission (2013) Homegrown Baltimore: grow local. Baltimore, MD. https://www.baltimoresustainability. org/projects/baltimore-food-policy-initiative/homegrownbaltimore/. Accessed March 2018

Barthel S, Folke C, Colding J (2010) Social-ecological memory in urban gardens - retaining the capacity for management of ecosystem services. Glob Environ Chang 20:255-265. https://doi.org/10.1016/j. gloenvcha.2010.01.001

Beninde J, Veith M, Hochkirch A (2015) Biodiversity in cities needs space: a meta-analysis of factors determining intra-urban biodiversity variation. Ecol Lett 18:581-592. https://doi.org/10.1111/ele. 12427

Bolund P, Hunhammer S (1999) Ecosystem services in urban areas. Ecol Econ 29:293-301. https://doi.org/10.1016/S0921-8009(99)00013-0

Burdine JD, Taylor DE (2017) Neighbourhood characteristics and urban gardens in the Toledo metropolitan area: staffing and voluntarism, food production, infrastructure, and sustainability practices. Local Environ 0:1-22. https://doi.org/10.1080/13549839.2017.1397614

Burks JM, Philpott SM (2017) Local and landscape drivers of parasitoid abundance, richness, and composition in urban gardens. Environ Entomol 46:1-9. https://doi.org/10.1093/ee/nvw175

Cadenasso ML, Pickett STA, Schwarz K et al (2007) Spatial heterogeneity in urban ecosystems: reconceptualizing land cover and a framework for classification. Front Ecol Environ 5:80-88

Chace JF, Walsh JJ (2006) Urban effects on native avifauna: a review. Landsc Urban Plan 74:46-69. https://doi.org/10.1016/j.landurbplan. 2004.08.007

Chiesura A (2004) The role of urban parks for the sustainable city. Landsc Urban Plan 68(1):129-138. https://doi.org/10.1016/j.landurbplan. 2003.08.003

City of Chicago Department of Planning and Development (2007) Chicago: eat local live healthy. Chicago, IL. https://www.chicago. gov/city/en/depts/dcd/supp info/eat local live healthy.html. Accessed March 2018

Clarke LM, Jenerette D (2015) Biodiversity and direct ecosystem service regulation in the community gardens of Los Angeles, CA. Landsc Ecol 30:367-653
Clarke M, Davidson M, Egerer M, Anderson E, Fouch N (2019) The underutilized role of community gardens in improving cities' adaptation to climate change: a review. People, Place and Policy 12(3): 241-251

Cook EA (2000) Ecological networks in urban landscapes. PhD dissertation, Wageningen University

Corlett JL, Dean EA, Grivetti LE (2003) Hmong gardens: botanical diversity in an urban setting. Econ Bot 57:365-379

Corrigan MP (2011) Growing what you eat: developing community gardens in Baltimore, Maryland. Appl Geogr 31:1232-1241. https:// doi.org/10.1016/j.apgeog.2011.01.017

Delmelle EC (2019) The increasing sociospatial fragmentation of urban America. Urban Sci 3:9

Eigenbrod F, Bell VA, Davies HN, Heinemeyer A, Armsworth PR, Gaston KJ (2011) The impact of projected increases in urbanization on ecosystem services. Proc R Soc B Biol Sci 278:3201-3208. https://doi.org/10.1098/rspb.2010.2754

Eizenberg E (2012) Actually existing commons: three moments of space of community gardens in New York City. Antipode 44:764-782. https://doi.org/10.1111/j.1467-8330.2011.00892.x

Fahey RT, Casali M (2017) Distribution of forest ecosystems over two centuries in a highly urbanized landscape. Landsc Urban Plan 164: $13-24$

Florida R, Adler P (2018) The patchwork metropolis: the morphology of the divided postindustrial city. J Urban Aff 40(5):609-624

Fuller RA, Irvine KN, Devine-wright P et al (2007) Psychological benefits of greenspace increase with biodiversity. Biol Lett 3:390-394. https://doi.org/10.1098/rsbl.2007.0149

Galluzzi G, Semi R, Group EC et al (2010) Home gardens: neglected hotspots of agro-biodiversity and cultural diversity. Biodivers Conserv 19:3635-3654. https://doi.org/10.1007/s10531-0109919-5

Gardiner MM, Prajzner SP, Burkman CE, Albro S, Grewal PS (2014) Vacant land conversion to community gardens: influences on generalist arthropod predators and biocontrol services in urban greenspaces. Urban Ecosyst 17:101-122. https://doi.org/10.1007/ s11252-013-0303-6

Gill SE, Handley JF, Ennos AR, Pauleit S (2007) Adapting cities for climate change: the role of the green infrastructure. Built Environ 33:115-133

Goddard MA, Dougill AJ, Benton TG (2010) Scaling up from gardens: biodiversity conservation in urban environments. Trends Ecol Evol 25:90-98. https://doi.org/10.1016/j.tree.2009.07.016

Grinde B, Patil GG (2009) Biophilia: does visual contact with nature impact on health and well-being? Int J Environ Res Public Health 6:2332-2343. https://doi.org/10.3390/ijerph6092332

Grove JM, Cadenasso ML, Pickett STA, Machlis GE, Burch, Jr. WR (2015) The Baltimore school of urban ecology: space, scale, and time for the study of cities. Yale University Press, New Haven

Guitart D, Pickering C, Byrne J (2012) Past results and future directions in urban community gardens research. Urban For Urban Green 11: 364-373. https://doi.org/10.1016/j.ufug.2012.06.007

Hansen R, Pauleit S (2014) From multifunctionality to multiple ecosystem services? A conceptual framework for multifunctionality in green infrastructure planning for Urban Areas. Ambio 43:516 529. https://doi.org/10.1007/s13280-014-0510-2

Hayden D (1997) The power of place: urban landscapes as public history. MIT press, Cambridge

Herrmann DL, Chuang W, Schwarz K et al (2018) Agroecology for the shrinking City. Sustainability 10:1-14. https://doi.org/10.3390/ su10030675

Hostetler M, Holling C (2000) Detecting the scales at which birds respond to structure in urban landscapes. Urban Ecosyst 4:25-54. https://doi.org/10.1023/A:1009587719462 
Kaplan R (1993) The role of nature in the context of the workplace. Landsc Urban Plan 26:193-201. https://doi.org/10.1016/01692046(93)90016-7

Kuo FE (2003) The role of arboriculture in a healthy social ecology. J Arboric 29:148-155

Larsen L, Adams J, Deal B, Kweon BS, Tyler E (1998) Plants in the workplace: the effects of plant density on productivity, attitudes, and perceptions. Environ Behav 30:261-281

Lawson LJ (2005) City bountiful: a century of community gardening in America. University of California Press, Ltd, Berkeley, Los Angeles, and London

Lin BB, Philpott SM, Jha S (2015) The future of urban agriculture and biodiversity-ecosystem services: challenges and next steps. Basic Appl Ecol 16:189-201. https://doi.org/10.1016/j.baae.2015.01.005

Lin BB, Egerer MH, Liere H, Jha S, Bichier P, Philpott SM (2018) Localand landscape-scale land cover affects microclimate and water use in urban gardens. Sci Total Environ 610-611:570-575. https://doi.org/ 10.1016/j.scitotenv.2017.08.091

Liskey AR (2017) Opportunities and challenges for improving security for vulnerable populations through meso-level collaboration in Baltimore, Maryland. Dissertation. University of Texas at Austin

Locke DH, Grove JM (2016) Doing the hard work where it's easiest? Examining the relationships between urban greening programs and social and ecological characteristics. Appl Spat Anal Policy 9:7796. https://doi.org/10.1007/s12061-014-9131-1

Lovell ST (2010) Multifunctional urban agriculture for sustainable land use planning in the United States. Sustainability 2:2499-2522. https://doi.org/10.3390/su2082499

Lovell ST, Taylor JR (2013) Supplying urban ecosystem services through multifunctional green infrastructure in the United States. Landsc Ecol 28:1447-1463. https://doi.org/10.1007/s10980-013-9912-y

Mathey J, Rößler S, Lehmann I, Bräuer A (2011) Urban green spaces: potentials and constraints for urban adaptation to climate change. In: Otto-Zimmermann K (ed) Resilient cities. Local sustainability, vol 1. Springer, Dordrecht

Matteson KC, Ascher JS, Langellotto GA (2008) Bee richness and abundance in New York City urban gardens. Ann Entomol Soc Am 101(1): 140-150. https://doi.org/10.1603/0013-8746(2008)101[140: BRAAIN]2.2. $\mathrm{C} 0 ; 2$

Minor ES, Anderson EC, Belair JA, Garfinkel M, Smith AD (2018) Urban green infrastructures and ecological networks for urban biodiversity conservation. Urban Biodiversity pp 186-199. Routledge in Association with GSF Research. https://doi.org/10.9774/GLEAF. 9781315402581_13

Moneo R (1978) On typology. Oppositions 13:24-46

Myint SW, Zheng B, Talen E, Fan C, Kaplan S, Middel A, Smith M, Huang HP, Brazel A (2015) Does the spatial arrangement of urban landscape matter? Examples of urban warming and cooling in Phoenix and Las Vegas. Ecosyst Heal Sustain 1:1-15

Nassauer JI, Raskin J (2014) Urban vacancy and land use legacies: a frontier for urban ecological research, design, and planning. Landsc Urban Plan 125:245-253. https://doi.org/10.1016/j. landurbplan.2013.10.008

Nowak DJ, Dwyer JF (2007) Understanding the benefits and costs of urban forest ecosystems. In: Kuser JE (ed) Urban and community forestry in the northeast. Springer, Dordrecht, pp 25-46. https://doi. org/10.1007/978-1-4020-4289-8 2

Ohmer ML, Meadowcroft P, Freed K, Lewis E (2009) Community gardening and community development: individual, social and community benefits of a community conservation program. J Community Pract 17:377-399. https://doi.org/10.1080/10705420903299961
Parker K, Head L, Chisholm LA, Feneley N (2008) A conceptual model of ecological connectivity in the Shellharbour local government area, New South Wales, Australia. Landsc Urban Plan 86:47-59

Philpott SM, Bichier P (2017) Local and landscape drivers of predation services in urban gardens. Ecol Appl 0:1-11. https://doi.org/10. 1002/eap. 1500

Pickett STA, Cadenasso ML, Grove JM, Boone CG, Groffman PM, Irwin E, Kaushal SS, Marshall V, McGrath BP, Nilon CH, Pouyat RV, Szlavecz K, Troy A, Warren P (2011) Urban ecological systems: scientific foundations and a decade of progress. J Environ Manag 92:331-362. https://doi.org/10.1016/j.jenvman.2010.08.022

Price C V, Nakagaki N, Hitt KJ (2010) National WATER-quality Assessment (NAWQA) area-characterization toolbox. US Geological Survey. https://doi.org/10.3133/ofr20101268

Pulighe G, Fava F, Lupia F (2016) Insights and opportunities from mapping ecosystem services of urban green spaces and potentials in planning. Ecosyst Serv 22:1-10. https://doi.org/10.1016/j.ecoser. 2016.09.004

Quistberg RD, Bichier P, Philpott SM (2016) Landscape and local correlates of bee abundance and species richness in urban gardens. Environ Entomol 0:1-10. https://doi.org/10.1093/ee/nvw025

Russell R, Guerry AD, Balvanera P, Gould RK, Basurto X, Chan KMA, Klain S, Levine J, Tam J (2013) Humans and nature: how knowing and experiencing nature affect well-being further. Annu Rev Environ Resour 38:473-502. https://doi.org/10.1146/annurevenviron-012312-110838

Saldivar-Tanaka L, Krasny ME (2004) Culturing neighborhood open space, civic agriculture, and community development: the case of Latino community gardens in New York City. Agric Hum Values 21:399-412

Sattler T, Borcard D, Arlettaz R, Bontadina F, Legendre P, Obrist MK, Moretti M (2010) Spider, bee, and bird communities in cities are shaped by environmental control and high stochasticity. Ecology 91: 3343-3353. https://doi.org/10.1890/09-1810.1

Schmelzkopf K (1995) Urban community gardens as contested space. Geogr Rev 85:364-381. https://doi.org/10.1038/126199a0

Schmelzkopf K (2002) Incommensurability, land use, and the right to space: community gardens in New York City. Urban Geogr 23: 323-343

Smith CM, Kurtz HE (2003) Community gardens and politics of scale in New York City. Geogr Rev 93(2):193-212. https://doi.org/10.1111/ j.1931-0846.2003.tb00029.x

Smith RM, Warren PH, Thompson K, Gaston KJ (2006) Urban domestic gardens (VI): environmental correlates of invertebrate species richness. Biodivers Conserv 15:2415-2438. https://doi.org/10.1007/ s10531-004-5014-0

Speak AF, Mizgajski A, Borysiak J (2015) Allotment gardens and parks: provision of ecosystem services with an emphasis on biodiversity. Urban For Urban Green 14:772-781

Staeheli LA, Mitchell D, Gibson K (2002) Conflicting rights to the city in New York's community gardens. GeoJournal 58:197-205

Sullivan WC, Kuo FE, DePooter SF (2004) The fruit of urban nature: vital neighborhood spaces. Environ Behav 36:678-700. https://doi. org/10.1177/0193841X04264945

Taylor JR, Lovell ST (2012) Mapping public and private spaces of urban agriculture in Chicago through the analysis of high-resolution aerial images in Google earth. Landsc Urban Plan 108:57-70. https://doi. org/10.1016/j.landurbplan.2012.08.001

The City of New York (2015) One New York: the plan for a strong and just city. https://www.nyc.gov/html/onenyc/downloads/pdf/ publications/OneNYC.pdf. Accessed March 2018 
Tzoulas K, Korpela K, Venn S, Yli-Pelkonen V, Kaźmierczak A, Niemela J, James P (2007) Promoting ecosystem and human health in urban areas using green infrastructure: a literature review. Landsc Urban Plan 81:167-178. https://doi.org/10.1016/j.landurbplan.2007.02. 001

United Nations, Department of Economic and Social Affairs PD (2015) World urbanization prospects: the 2014 revision. New York, NY

United States Census Bureau (2014) American Community Survey Data. www.census.gov/acs/www/data/data-tables-and-tools/ data-profiles/2014/. Accessed Jan 2018

US Census Bureau (2014) American fact finder. Washington, D.C. https:/www.factfinder.census/gov/faces/nav/jsf/pages/index.xhtml. Accessed Jan 2018
US Census Bureau (2016) TIGER/Line ${ }^{\circledR}$ Shapefiles and TIGER/Line $®$ Files. In: Geography. https:/www.census.gov/geo/maps-data/data/ tiger-line.html. Accessed 14 Oct 2017

Walker RE, Keane CR, Burke JG (2010) Disparities and access to healthy food in the United States: a review of food deserts literature. Health Place 16:876-884. https://doi.org/10.1016/j.healthplace.2010.04.013

Wolch JR, Byrne J, Newell JP (2014) Urban green space, public health, and environmental justice: the challenge of making cities 'just green enough'. Landsc Urban Plan 125:234-244

Zipperer WC, Wu J, Pouyat RV, Pickett STA (2000) the application of ecological principles to urban and urbanizing landscapes. Ecol Appl $10: 685-688$ 